\title{
Methylene: The Linker of Two Aromatic Iminium Salts
}

\author{
Anurag Noonikara-Poyil ${ }^{1}$, Enrique Barragan ${ }^{1}$, Siddappa Patil ${ }^{2}$ and Alejandro Bugarin ${ }^{1,3, *}$ \\ ${ }^{1}$ Department of Chemistry and Biochemistry, University of Texas at Arlington, TX 76019, USA \\ ${ }^{2}$ Centre for Nano and Material Sciences, Jain Global Campus, Bangalore 562112, Karnataka, India \\ ${ }^{3}$ Department of Chemistry and Physics, Florida Gulf Coast University, FL 33965, USA \\ *Corresponding author: Alejandro Bugarin, e-mail: abugarin@fgcu.edu Tel.: +1 239 745-4464; fax: +1 \\ $239590-1878$
}

Received March 30"th, 2018 ; Accepted October 17 ${ }^{\text {th }}, 2018$.

DOI: http://dx.doi.org/10.29356/jmcs.v63i3.525

\begin{abstract}
A straightforward synthesis of aromatic iminium salts has been developed by coupling 2-Azido1,3,5-trimethyl benzene with 1,3-ditert-butylimidazolium tetrafluoroborate in basic conditions, followed by treatment with dichloromethane or iodomethane. Herein, we report the synthetic procedure and full characterization data, including X-ray structure analysis, of the expected bis(triazenyl)methane adduct 5 . Moreover, we have discovered what constitutes a double carbon-chlorine bond activation.

Keywords: aromatic iminium salts; $\pi$-conjugated triazene; $x$-ray structure; iodomethane; methylene chloride.
\end{abstract}

Resumen. Una síntesis directa de sales iminio aromáticas se ha desarrollado mediante el acoplamiento entre el 2-azido-1,3,5-trimetil benceno y el tetrafluoroborato de 1,3-ditert-butilimidazolio en condiciones básicas, seguido por su tratamiento con diclorometano o iodometano. Aquí, reportamos el proceso sintético y la caracterización completa, incluyendo análisis de rayos-X, del aducto esperado bis(triazenil)metano 5 . Además, hemos descubierto lo que constituye una doble activación de enlace carbono-cloro.

Palabras clave: sales iminio aromáticas; triazeno $\pi$-conjugado; estructura de rayos-X; iodometano; cloruro de metileno.

\section{Introduction}

Synthesis of nitrogen-containing molecules is of significant importance because of their occurrence in a myriad of chemicals, materials, natural products, pharmaceuticals, etc. [1-3]. Nitrogen-atoms present in organic compounds can be arranged in many different ways. These combinations and/or permutations of nitrogen-atoms give rise to many different functional groups, such as: amines, guanidines, ureas, lactams, amides, azides, amino acids, nucleic acids, pyridines, triazenes, etc. [4,5]. In 2014, our laboratory reported a straightforward method for the synthesis of nitrogen-enriched $\pi$-conjugated triazenes [6,7], (Fig.1). Due to the current scientific interest and known applications of $\pi$-conjugated triazenes, a review on the subject appeared in the literature in 2015 [8]. Figure 1 also shows two molecules with similar chemical structures that were reported last year and voted as top molecules of the year, due to their unique electronic and structure properties $[9,10]$. The chemical structure of these molecules includes three continuous nitrogen-atoms, one of the compounds serves as frustrated Lewis acid pair (Triazolium) [9], while the other molecule was the first stabilized radical using an $N$-heterocyclic carbene (NHC) [10], (Fig, 1). Herein, we report the synthesis and 
characterization of two aromatic iminium salts linked by methylene derivated from dichloromethane (Fig. 1). This due to our interest in increasing molecular complexity and to further evaluate the chemical reactivity of $\pi$ conjugated triazenes [11,12].

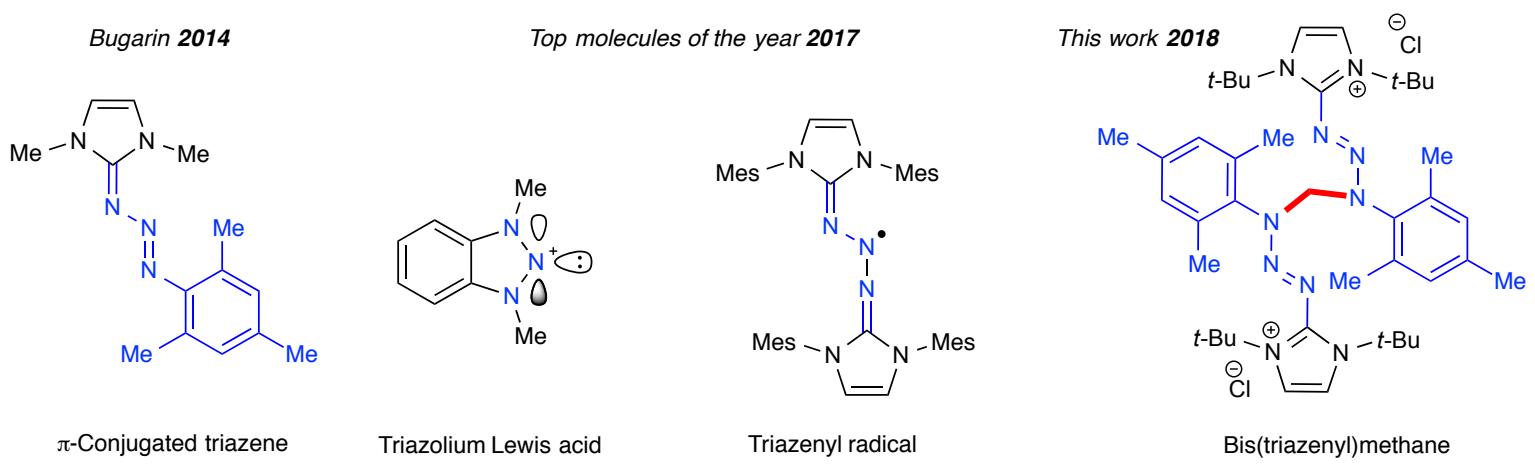

Fig. 1. Examples of nitrogen-containing molecules with unique structure and electronic properties. Mes $=$ Mesityl.

The activation of chloroalkanes represents a considerable challenge in synthetic chemistry since the $\mathrm{C}-\mathrm{Cl}$ bond is relatively inert compared with its congeners $\mathrm{C}-\mathrm{Br}$ and $\mathrm{C}-\mathrm{I}$ bonds [13]. It is of additional difficulty to activate both $\mathrm{C}-\mathrm{Cl}$ bonds of a gem-dichloroalkane, for example dichloromethane [14]. Dibromomethane and diiodomethane have been used as alkylating agents (e.g., Simmons-Smith cyclopropanation), [15]. However, dichloromethane a substantially cheaper compound is considerably less exploited, because of its much lower reactivity as described above [16]. Therefore, we aimed to evaluate the nucleophilic power of our $\pi$-conjugated triazene toward alkylation with the less reactive methylene chloride. Because our $\pi$-conjugated triazene has several nucleophilic nitrogens (Fig. 1), we also investigated the regioselectivity of this alkylation reaction and the results are presented below in this manuscript.

\section{Experimental}

\section{General Information}

All reactions were carried out in oven-dried glassware with magnetic stirring. The NHC precursor 1,3di-tert-butylimidazolium tetrafluoroborate and 2-Azido-1,3,5-trimethyl benzene were prepared according to known literature procedures [16,17]. Solvents were dried and degassed from a solvent purification system. Purification of reaction products was carried out by flash column chromatography using silica gel 60 (230-400 mesh) or by re-crystallization. TLC visualization was accompanied by UV light and $\mathrm{KMnO}_{4}$ stain. The removal of volatile solvent was accomplished using a rotary evaporator attached to a dry diaphragm pump (10-15 $\mathrm{mmHg})$ followed by pumping to a constant weight with an oil pump ( $<300 \mathrm{mTorr}) .{ }^{1} \mathrm{H}$ NMR spectra were recorded at $500 \mathrm{MHz}$ and are reported relative to DMSO- $d 6(\delta 2.50)$. ${ }^{1} \mathrm{H}$ NMR coupling constants $(\mathrm{J})$ are reported in hertz $(\mathrm{Hz})$, and multiplicities are indicated as follows: $\mathrm{s}$ (singlet), $\mathrm{d}$ (doublet), $\mathrm{t}$ (triplet), $\mathrm{m}$ (multiplet). Proton-decoupled ${ }^{13} \mathrm{C}$ NMR spectra were recorded at $125 \mathrm{MHz}$ and reported relative to DMSO- $d 6$ $(\delta 39.52)$. IR experiments were recorded with neat samples on an instrument fitted with a diamond ATR sample plate. High-resolution (HR) mass spectra were recorded using an ESI-TOF instrument. X-ray diffraction data for compound 5 were collected on a Bruker CCD diffractometer equipped with graphite monochromated MoKla radiation $(\mathrm{k}=0.71073 \AA)$ at room temperature. Analytical absorption corrections based on the shape of the crystals were performed. Hydrogen atoms were added at calculated positions and refined using a riding model. Anisotropic thermal displacement parameters were used for all non-disordered non-hydrogen atoms. 
Synthesis of $(E)$-1,3-di-tert-butyl-2-(mesityltriaz-2-en-1-ylidene)-2,3-dihydro-1 $H$-imidazole (3):

2-Azido-1,3,5-trimethyl benzene $2(161 \mathrm{mg}, 1.0 \mathrm{mmol})$ was added in one portion to a stirred suspension of 1,3-di-tert-butylimidazolium tetrafluoroborate $1(224 \mathrm{mg}, 1.0 \mathrm{mmol})$ in dry THF $(5 \mathrm{~mL})$. After stirring the reaction mixture for 5 minutes, $\mathrm{NaH}(40 \mathrm{mg}, 1.5 \mathrm{mmol}, 1.5$ equiv, $60 \%$ in mineral oil) was added in one portion and the resulting mixture was stirred for $12 \mathrm{~h}$ at room temperature under argon. Hexanes $(5 \mathrm{~mL})$ were added to the reaction and this mixture was filtered through Celite. The filtrate was concentrated using a rotary evaporator and further dried using high vacuum, affording the pure triazene 3 as a yellow solid (297 mg, 87\%). ${ }^{1} \mathrm{H}$ NMR (DMSO- $\left.d_{6}, 500 \mathrm{MHz}\right): \delta 7.12(\mathrm{~s}, 2 \mathrm{H}), 6.75(\mathrm{~s}, 2 \mathrm{H}), 2.18(\mathrm{~s}, 3 \mathrm{H}), 2.05(\mathrm{~s}, 6 \mathrm{H}), 1.50(\mathrm{~s}, 18 \mathrm{H})$; ${ }^{13} \mathrm{C}$ NMR (DMSO- $d_{6}, 125 \mathrm{MHz}$ ): $\delta$ 154.0, 148.7, 131.4, 128.8, 128.6, 113.1, 58.2, 29.3, 20.4, 18.6. IR (neat) $v$ $3490,1609,1392,1249 \mathrm{~cm}^{-1}$. Melting point $=104-106{ }^{\circ} \mathrm{C}$. HRMS (ESI, $\left.\mathrm{N}_{2}\right): \mathrm{m} / \mathrm{z}$ calcd for $\mathrm{C}_{20} \mathrm{H}_{32} \mathrm{~N}_{5}[\mathrm{M}+\mathrm{H}]^{+}$ 342.2652 , found 342.2649 .

\section{Synthesis of (E)-1,3-di-tert-butyl-2-(3-mesityl-3-methyltriaz-1-en-1-yl)-1H-imidazol-3-ium iodide (4):}

In a $10 \mathrm{~mL}$ round bottom flask equipped with a magnetic stir bar, $(E)$-1,3-di-tert-butyl-2-(mesityltriaz2-en-1-ylidene)-2,3-dihydro- $1 H$-imidazole $3(50 \mathrm{mg}, 0.3 \mathrm{mmol}, 1$ equiv) was dissolved in $5 \mathrm{~mL}$ of dichloromethane, then $\mathrm{MeI}(0.4 \mathrm{~mL}, 0.6 \mathrm{mmol}, 2.0$ equiv) was added to the reaction mixture and stirred at room temperature for $4 \mathrm{~h}$. After this time, all the volatiles were removed under reduced pressure, yielding pure product as a pale orange solid (122 mg, $>99 \%) .{ }^{1} \mathrm{H}$ NMR (DMSO- $\left.d_{6}, 500 \mathrm{MHz}\right): \delta 7.81(\mathrm{~s}, 2 \mathrm{H}), 7.08(\mathrm{~s}, 2 \mathrm{H}), 3.73(\mathrm{~s}$, $3 \mathrm{H}), 2.28(\mathrm{~s}, 3 \mathrm{H}), 2.18(\mathrm{~s}, 6 \mathrm{H}), 1.57(\mathrm{~s}, 18 \mathrm{H}) ;{ }^{13} \mathrm{C}$ NMR (DMSO-d, $\left.125 \mathrm{MHz}\right): \delta 146.38,139.16,139.02$, 134.22, 129.51, 117.60, 66.98, 61.42, 29.48, 20.52, 17.56. IR (neat) v 3158, 2972, 2119, 1563, $1447 \mathrm{~cm}^{-1}$. Melting point $=164-166^{\circ} \mathrm{C}$. HRMS $\left(E S I, \mathrm{~N}_{2}\right): \mathrm{m} / \mathrm{z}$ calcd for $\mathrm{C}_{21} \mathrm{H}_{34} \mathrm{~N}_{5}[\mathrm{M}-\mathrm{I}]^{+} 356.2809$, found 356.2810.

\section{Synthesis of 2,2'-((1E,1'E)-methylenebis(3-mesityltriaz-1-ene-3,1-diyl))bis(1,3-di-tert-butyl-1H-} imidazol-3-ium) chloride (5):

To a $5 \mathrm{~mL}$ round bottom flask was added (E)-1,3-di-tert-butyl-2-(mesityltriaz-2-en-1-ylidene)-2,3dihydro- $1 \mathrm{H}$-imidazole $3(200 \mathrm{mg}, 1.2 \mathrm{mmol})$ and methylene chloride $(1 \mathrm{~mL})$ at room temperature and the round bottom flask was capped with a red-rubber septum. Then, a needle was pierced into the septa to allow slow evaporation of the solvent. The reaction mixture was left undisturbed for 3 days, away from light. After this period of time, colorless crystals were formed, collected (41\%), and fully characterized. ${ }^{1} \mathrm{H}$ NMR (DMSO- $d_{6}$, $500 \mathrm{MHz}): \delta 7.73(\mathrm{~d}, J=1.0 \mathrm{~Hz}, 4 \mathrm{H}), 7.11(\mathrm{~s}, 4 \mathrm{H}), 6.69\left(\mathrm{~s}, 2 \mathrm{H},-\mathrm{CH}_{2}-\right), 2.30(\mathrm{~s}, 6 \mathrm{H}), 2.08(\mathrm{~s}, 12 \mathrm{H}), 1.28(\mathrm{~s}$, $36 \mathrm{H}) ;{ }^{13} \mathrm{C}$ NMR (DMSO- $\left.d_{6}, 125 \mathrm{MHz}\right): \delta 144.1,140.2,135.1,134.3,129.9,118.7,76.5\left(-\mathrm{CH}_{2-}\right), 62.3,29.1$, 20.7, 19.1. IR (neat) $\vee 3377,1606,1368,1232 \mathrm{~cm}^{-1}$. Melting point $=144-147^{\circ} \mathrm{C}$. HRMS (ESI, $\mathrm{N}_{2}$ ): $\mathrm{m} / \mathrm{z}$ calcd for $\mathrm{C}_{41} \mathrm{H}_{64} \mathrm{~N}_{10}[\mathrm{M}-2 \mathrm{Cl}]^{2+} 348.2652$, found 348.2650.

\section{Results and Discussion}

\section{Chemistry}

The $N$-heterocyclic carbene (NHC) precursor 1,3-di-tert-butyl- $1 H$-imidazol-3-ium tetrafluoroborate 1 and 2-azido-1,3,5-trimethylbenzene 2 were prepared according to known literature procedures $[17,18]$. It is worth noting that NHC precursor 1 is also commercially available. With both starting materials on hand, we proceeded to suspend the insoluble NHC precursor 1 in dry tetrahydrofuran (THF), followed by addition of 1.5 equivalents of sodium hydride $(\mathrm{NaH})$. The reaction mixture was stirred at room temperature for 20 minutes, to allow formation of the carbene intermediate, which is soluble in THF. Then, organic azide 2 was slowly added to the reaction mixture and stirred at room temperature for $12 \mathrm{~h}$. The stirring was stopped and to the reaction mixture was added hexanes to precipitate the sodium tetrafluoroborate byproduct and was eliminated by vacuum filtration. Lastly, the yellow liquid filtrate was concentrated under reduced pressure to afford the desired (E)-1,3-di-tert-butyl-2-(mesityltriaz-2-en-1-ylidene)-2,3-dihydro- $H$-imidazole ( $\pi$-conjugated triazene 3 ), as a yellow solid in $89 \%$ yield (Scheme 1). 


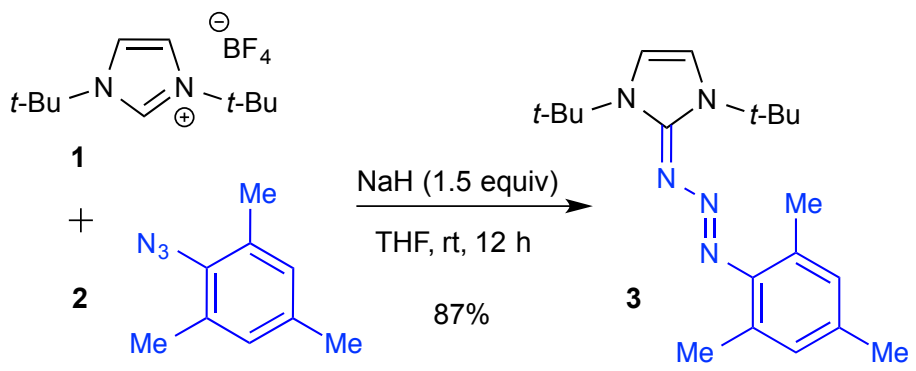

Scheme 1: Synthesis of $\pi$-conjugated triazene 3.

The freshly prepared $\pi$-conjugated triazene 3 was reacted with 2.0 equivalents of iodomethane at room temperature, using dichloromethane as a solvent. After $12 \mathrm{~h}$ of stirring, all volatiles were removed under reduced pressure to afford pure (E)-1,3-di-tert-butyl-2-(3-mesityl-3-methyltriaz-1-en-1-yl)-1H-imidazol-3-ium iodide 4 , as a pale orange solid in quantitative yield (Scheme 2). It was exciting to observe a single regioisomer, where the methyl group was added to the nitrogen-atom next to the mesityl group. This outcome represents a highly regioselective example of an extremely efficient and mild alkylation of $\pi$-conjugated triazenes, even in the presence of two ortho methyl groups from the mesityl moiety (Scheme 2).

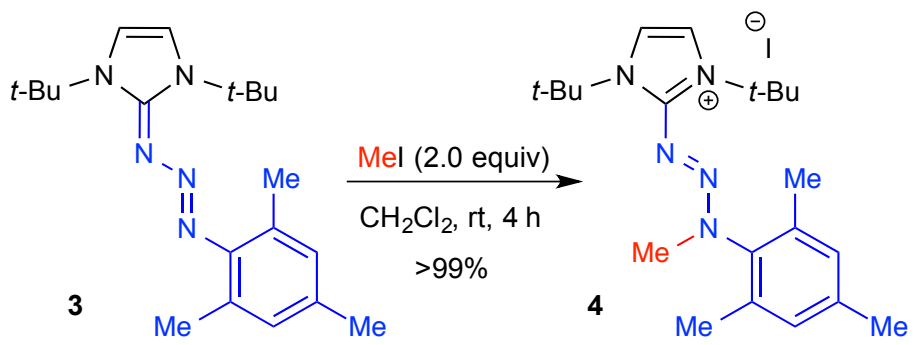

Scheme 2: Regioselective alkylation of $\pi$-conjugated triazene 3, with iodomethane.

In addition, using the same freshly prepared $\pi$-conjugated triazene 3 and to further demonstrate the nucleophilic ability of the nitrogen-atom proximal to mesityl group. $\pi$-Conjugated triazene 3 was dissolved in dichloromethane and allowed to precipitate, for 3 days. This time, dichloromethane was used as the solvent and the reagent (Scheme 3). To our delight, quantitative conversion was observed, and excellent crystals were formed, isolated, and fully characterized. The chemical structure of these crystals was confirmed to be 2,2'$\left(\left(1 E, 1^{\prime} E\right)\right.$-methylenebis(3-mesityltriaz-1-ene-3,1-diyl))bis(1,3-di-tert-butyl-1H-imidazol-3-ium) chloride 5 (Scheme 3). Again, it was breathtaking to discover a single regioisomer, where the methylene group was added to the same nitrogen-atom of both molecules. Additionally, these results indicate that carbon-chloride bond activation is highly favored using $\pi$-conjugated triazenes, such as 3 (Scheme 3 ). It is also important to note that both carbon-chlorine bonds were activated/substituted. To further understand the carbon-halide activation and to obtain additional insight into the reaction mechanism, a small set of experiments employing dichloromethane $\left(\mathrm{CH}_{2} \mathrm{Cl}_{2}\right)$, dibromomethane $\left(\mathrm{CH}_{2} \mathrm{Br}_{2}\right)$, and diiodomethane $\left(\mathrm{CH}_{2} \mathrm{I}_{2}\right)$ were conducted. Starting material (3) was consumed after 1 day using $\mathrm{CH}_{2} \mathrm{I}_{2}, 2$ days with $\mathrm{CH}_{2} \mathrm{Br}_{2}$, and 3 days with $\mathrm{CH}_{2} \mathrm{Cl}_{2}$, which is in agreement with the known properties of halides as leaving groups. Although, diiodomethane reacted relatively faster compared with its counterparts, it was difficult to dissolve the triazene in this solvent, and additional heating was required, before stirring the reaction at room temperature for $1 \mathrm{~d}$. It is worth noting that the dimeric adduct 5 was obtained even in the presence of excess dihalomethanes, thus indicating that the initial monoalkylated intermediate undergoes a halide elimination, driven by the adjacent nitrogen lone pair, to form an iminium ion 
(Eschenmoser's salt). This iminium ion (observed by ${ }^{1} \mathrm{H}$ NMR) is trapped by another triazene molecule, delivering the final dimeric compound 5. This mechanistic sequence favors the formation of dimeric compound versus monomer since the iminium ion is considerably more electrophilic than the dihalomethanes present in the reaction mixture. Furthermore, during our efforts to obtain good quality crystals, for solid state studies, we found that the aromatic iminium salt derivated from $\mathrm{CH}_{2} \mathrm{Cl}_{2}$ (i.e., 5) formed better crystals, whereas diiodo- and dibromomethane showed higher product decomposition, we believe this is due to the nucleophilicity of both bromine and iodine ions, which could react with the adduct. Therefore, dichloromethane was our preferred choice due to its lower boiling point (easier to remove from the reaction mixture) and of course its considerable lowest price. Finally, the observed double regioselective alkylation of an already highly hindered intermediate to afford compound 5 is potentially due to the electron-density on the NHC moiety, while maintaining $\pi$ conjugation with the aromatic imidazolium salt.

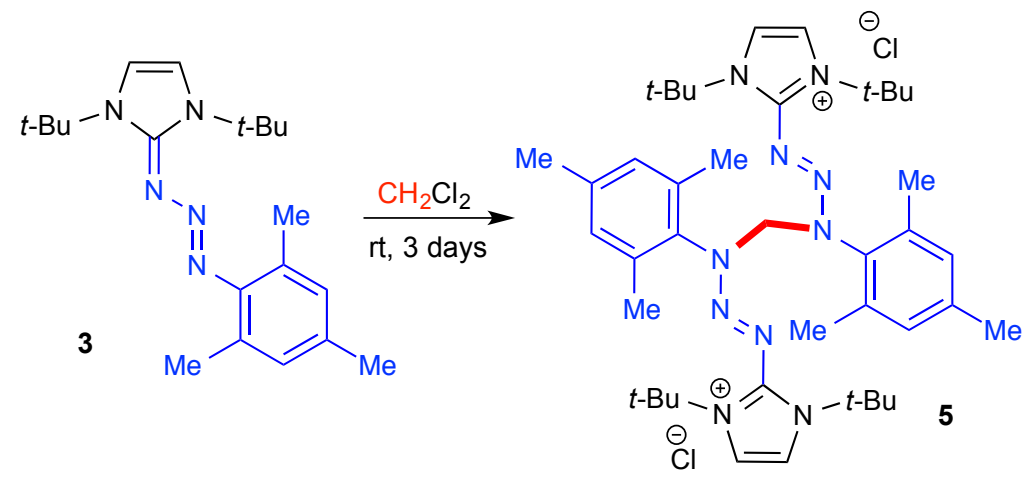

Scheme 3: Synthesis of the double aromatic imidazolium salt (compound 5), using methylene chloride.

\section{X-Ray Crystal Structure}

Single crystals of compound 5 were grown by slow evaporation of a solution of 5 in dichloromethane, at room temperature. Its solid-state structure was established by single crystal X-ray diffraction analysis. The ORTEP and molecular packing diagrams are shown in Figures 2 and 3, respectively. Details of crystal structure, data collection, and structure refinement are summarized in Table 1. Likewise, the pertinent bond angles and lengths of the compound 5 are tabulated in Table 2 . The molecule crystallizes in the triclinic system with the space group P-1(\#2), with $\beta=85.554(5)^{\circ}$. The cell dimensions are $a=12.104(5) \AA, b=13.182(5) \AA$ and $c=$ $15.742(4) \AA$ and volume $=2467.584 \AA^{3}$. The crystal structure of compound 5 reveals that the five and six membered rings are not in the same plane. The crystal structure consists of two cations [mesitylene triazene] ${ }^{+}$ and two $\mathrm{Cl}^{-}$anions. Consequently, the charges on compound 5 are neutralized by the presence of two $\mathrm{Cl}$ anions in the crystal lattice. Furthermore, compound 5 does not contain any organic solvent molecules or lattice held water molecules in the unit cell of the determined structure. The bond lengths and angles in the five membered rings (NCNCC) compare well with similar reported compounds [1-(4-chlorophenyl-3-(1,3-dimethylimidazol2-ylidene)triazene and 1-(3-nitrophenyl-3-(1,3-dimethylimidazol-2-ylidene)triazene] [6,7]. The C-C bond lengths in phenyl rings are in the normal range of 1.28-1.57 $\AA$, which is characteristic of delocalized benzene rings. The $\mathrm{C}-\mathrm{C}-\mathrm{C}$ bond angles in phenyl rings are close to $120^{\circ}$, it suggests that carbon atoms are $\mathrm{sp}^{2}$ hybridized. Furthermore, compound 5 lies in three planes with plane I [C(2), N(1), C(35), C(34), N(10), C(3), C(36), C(29), $\mathrm{N}(9), \mathrm{C}(28), \mathrm{C}(27), \mathrm{N}(8), \mathrm{C}(6)$ and $\mathrm{C}(5)]$ making a dihedral angle of $87.39^{\circ}$ and $78.14^{\circ}$ with plane $\mathrm{II}[\mathrm{C}(21)$, $\mathrm{C}(20), \mathrm{C}(19), \mathrm{C}(18), \mathrm{C}(23), \mathrm{C}(22), \mathrm{C}(26), \mathrm{C}(25), \mathrm{C}(9), \mathrm{C}(10), \mathrm{C}(11), \mathrm{C}(12), \mathrm{C}(14), \mathrm{C}(15), \mathrm{C}(13)$ and $\mathrm{C}(16)$ ] and plane III $[\mathrm{N}(7), \mathrm{N}(6), \mathrm{N}(5), \mathrm{C}(4), \mathrm{N}(2), \mathrm{N}(3)$, and $\mathrm{N}(4)]$, whereas plane II forms a dihedral angle of $75.25^{\circ}$ with plane III. The molecular packing diagram shows two molecules, which are independently arranged in the unit cell without the involvement of intra- or intermolecular hydrogen bonds (Fig. 3). Finally, the crystallographic data with the structural analysis have been deposited in the Cambridge Crystallographic Data Centre and the CCDC 1832942 contains the supplementary crystallographic data for the present work. This 
data can be obtained free of charge at www.ccdc.cam.ac.uk/data request/cif using CCDC 1832942 as the deposition number [19].

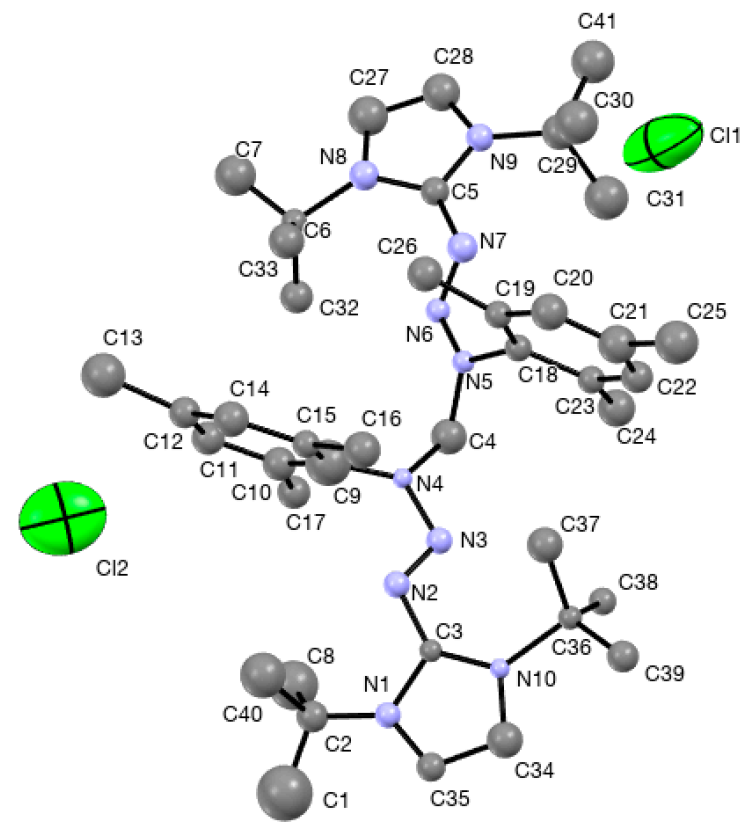

Fig. 2. ORTEP representation of the $\mathrm{X}$-ray crystal structure of compound 5 showing atom labeling. 50\% Probability amplitude displacement ellipsoids are shown. For clarity, all hydrogen atoms are omitted.

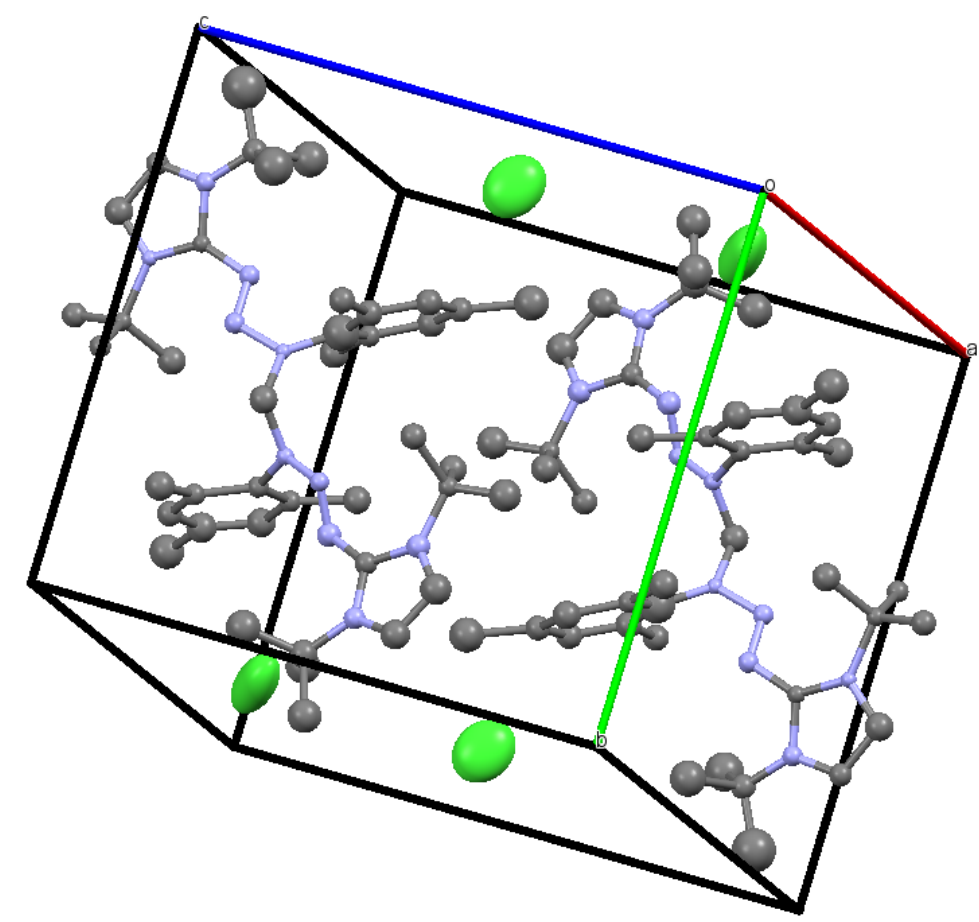

Fig. 3. Molecular packing diagram of compound 5. 
Table 1. Crystal data and structure refinement data for compound 5.

\begin{tabular}{|l|l|}
\hline Molecular formula & $\mathrm{C}_{41} \mathrm{H}_{64} \mathrm{Cl}_{2} \mathrm{~N}_{10}$ \\
\hline Formula weight & 767.9 \\
\hline Temperature & $100(2) \mathrm{K}$ \\
\hline Wavelength & $\AA$ \\
\hline Crystal system & Triclinic \\
\hline Space group & $\mathrm{P}-1(\# 2)$ \\
\hline Unit cell dimensions & $a=12.104(5) \AA \quad \alpha=89.904(5)^{\circ}$. \\
\hline & $b=13.182(5) \AA \quad \beta=85.554(5)^{\circ}$. \\
\hline & $c=15.742(4) \AA \quad \gamma=80.199(5)^{\circ}$. \\
\hline Volume & $2467.584 \AA 3$ \\
\hline Z & 2 \\
\hline Density (calculated) & $1.0336 \mathrm{Mg} / \mathrm{m}^{3}$ \\
\hline Absorption coefficient & $0.167 \mathrm{~mm}^{-1}$ \\
\hline F(000) & 828 \\
\hline Crystal size & $0.16 \times 0.16 \times 0.055 \mathrm{~mm}{ }^{3}$ \\
\hline Theta range for data collection & 2.9 to $26.95^{\circ}$ \\
\hline Index ranges & $-12<=\mathrm{h}<=12,-13<=\mathrm{k}<=13,-15<=1<=15$ \\
\hline Reflections collected & 14524 \\
\hline Independent reflections & $5313[\mathrm{R}(\mathrm{int})=0.0422]$ \\
\hline Completeness to theta $=\mathbf{2 6 . 9 5}{ }^{\circ}$ & $100.0 \%$ \\
\hline Absorption process & $\mathrm{Semi}-\mathrm{empirical}$ \\
\hline Max. and min. transmission & 0.974 and 0.991 \\
\hline Data / restraints / parameters & $2266 / 0 / 223$ \\
\hline Radiation & $0.71073(\AA)$ \\
\hline Goodness-of-fit on F2 & 1.52 \\
\hline Final R indices [I $>2$ sigma(I)] & $\mathrm{R} 1=0.0517, \mathrm{wR} 2=0.0470$ \\
\hline R indices (all data) & $\mathrm{R} 1=0.0517, \mathrm{wR} 2=0.0470$ \\
\hline Largest diff. peak and hole & 0.10 and $-0.07 \mathrm{e} . \AA-3$ \\
\hline & \\
\hline
\end{tabular}

Table 2. Selected bond lengths $[\AA]$ and angles $\left[^{\circ}\right]$ for compound 5 .

\begin{tabular}{|c|c|c|c|}
\hline Bond lengths $[\AA \boldsymbol{\AA}]$ & $\mathbf{5}$ & Bond lengths $[\AA \mathbf{\AA}]$ & $\mathbf{5}$ \\
\hline $\mathrm{N}(1)-\mathrm{C}(2)$ & $1.409(7)$ & $\mathrm{N}(7)-\mathrm{C}(5)$ & $1.458(7)$ \\
\hline $\mathrm{N}(1)-\mathrm{C}(3)$ & $1.397(7)$ & $\mathrm{N}(8)-\mathrm{C}(5)$ & $1.394(7)$ \\
\hline $\mathrm{N}(1)-\mathrm{C}(35)$ & $1.300(7)$ & $\mathrm{N}(8)-\mathrm{C}(6)$ & $1.519(7)$ \\
\hline $\mathrm{N}(2)-\mathrm{N}(3)$ & $1.287(6)$ & $\mathrm{N}(8)-\mathrm{C}(27)$ & $1.324(9)$ \\
\hline $\mathrm{N}(2)-\mathrm{C}(3)$ & $1.394(6)$ & $\mathrm{N}(9)-\mathrm{C}(5)$ & $1.335(7)$ \\
\hline $\mathrm{N}(3)-\mathrm{N}(4)$ & $1.360(6)$ & $\mathrm{N}(9)-\mathrm{C}(28)$ & $1.351(8)$ \\
\hline $\mathrm{N}(4)-\mathrm{C}(4)$ & $1.476(7)$ & $\mathrm{N}(9)-\mathrm{C}(29)$ & $1.474(8)$ \\
\hline $\mathrm{N}(4)-\mathrm{C}(9)$ & $1.393(5)$ & $\mathrm{N}(10)-\mathrm{C}(3)$ & $1.358(6)$ \\
\hline $\mathrm{N}(5)-\mathrm{N}(6)$ & $1.293(6)$ & $\mathrm{N}(10)-\mathrm{C}(34)$ & $1.317(8)$ \\
\hline $\mathrm{N}(5)-\mathrm{C}(4)$ & $1.444(8)$ & $\mathrm{N}(10)-\mathrm{C}(36)$ & $1.575(6)$ \\
\hline $\mathrm{N}(5)-\mathrm{C}(18)$ & $1.450(7)$ & $\mathrm{C}(27)-\mathrm{C}(28)$ & $1.387(10)$ \\
\hline $\mathrm{N}(6)-\mathrm{N}(7)$ & $1.251(6)$ & $\mathrm{C}(34)-\mathrm{C}(35)$ & $1.438(9)$ \\
\hline Bond angles $\left[{ }^{\circ}\right]$ & $\mathbf{5}$ & $\mathbf{B o n d}$ angles $\left[{ }^{\circ}\right]$ & $\mathbf{5}$ \\
\hline $\mathrm{C}(2)-\mathrm{N}(1)-\mathrm{C}(3)$ & $123.5(4)$ & $\mathrm{N}(5)-\mathrm{N}(6)-\mathrm{N}(7)$ & $113.2(4)$ \\
\hline $\mathrm{C}(2)-\mathrm{N}(1)-\mathrm{C}(35)$ & $130.8(5)$ & $\mathrm{N}(6)-\mathrm{N}(7)-\mathrm{C}(5)$ & $112.2(5)$ \\
\hline $\mathrm{C}(3)-\mathrm{N}(1)-\mathrm{C}(35)$ & $105.5(4)$ & $\mathrm{C}(5)-\mathrm{N}(8)-\mathrm{C}(6)$ & $128.3(4)$ \\
\hline
\end{tabular}




\begin{tabular}{|c|c|c|c|}
\hline $\mathrm{N}(3)-\mathrm{N}(2)-\mathrm{C}(3)$ & $114.0(4)$ & $\mathrm{C}(5)-\mathrm{N}(8)-\mathrm{C}(27)$ & $108.6(5)$ \\
\hline $\mathrm{N}(2)-\mathrm{N}(3)-\mathrm{N}(4)$ & $111.2(4)$ & $\mathrm{C}(6)-\mathrm{N}(8)-\mathrm{C}(27)$ & $122.6(5)$ \\
\hline $\mathrm{N}(3)-\mathrm{N}(4)-\mathrm{C}(4)$ & $108.8(4)$ & $\mathrm{C}(5)-\mathrm{N}(9)-\mathrm{C}(28)$ & $108.9(5)$ \\
\hline $\mathrm{N}(3)-\mathrm{N}(4)-\mathrm{C}(9)$ & $125.6(3)$ & $\mathrm{C}(5)-\mathrm{N}(9)-\mathrm{C}(29)$ & $125.4(5)$ \\
\hline $\mathrm{C}(4)-\mathrm{N}(4)-\mathrm{C}(9)$ & $124.6(4)$ & $\mathrm{C}(28)-\mathrm{N}(9)-\mathrm{C}(29)$ & $125.6(5)$ \\
\hline $\mathrm{N}(6)-\mathrm{N}(5)-\mathrm{C}(4)$ & $114.5(4)$ & $\mathrm{C}(3)-\mathrm{N}(10)-\mathrm{C}(34)$ & $111.1(4)$ \\
\hline $\mathrm{N}(6)-\mathrm{N}(5)-\mathrm{C}(18)$ & $123.0(4)$ & $\mathrm{C}(3)-\mathrm{N}(10)-\mathrm{C}(36)$ & $128.9(4)$ \\
\hline $\mathrm{C}(4)-\mathrm{N}(5)-\mathrm{C}(18)$ & $120.6(4)$ & $\mathrm{C}(34)-\mathrm{N}(10)-\mathrm{C}(36)$ & $119.9(4)$ \\
\hline
\end{tabular}

\section{Conclusion}

A two-step synthesis of a couple of aromatic iminium salts has been developed, starting from readily available mesityl azide. All the experiments were conducted at room temperature, without using specialized equipment or anhydrous conditions. In addition, we observed a regioselective alkylation employing both iodomethane and methylene chloride. Therefore, we established that the nitrogen-atom next to the mesityl group is quite more nucleophilic than any other nitrogen-atoms presented in the triazene intermediate. Furthermore, isolation of a single regioisomer in high yields for each of the reported alkylation reactions supports the preceding statement.

\section{Acknowledgment}

The Universities of Texas at Arlington and Florida Gulf Coast University partially supported this work. In addition, the authors acknowledge the financial support of the ACS PRF-ND award (58269-ND1). Furthermore, we would like to thank Dr. Delphine Gout for the X-ray data collection.

\section{References}

1. Howell, J. M.; Feng, K.; Clark, J. R.; Trzepkowski, L. J.; White, M. C. J. Am. Chem. Soc. 2015, 137, 14590-14593.

2. Andrez, J.-C. Beilstein J. Org. Chem. 2009, 5, 33.

3. Baumann, M.; Baxendale, I. R.; Ley, S. V.; Nikbin, N. Beilstein J. Org. Chem. 2011, 7, 442-495.

4. Assary, R. S.; Brushett, F. R.; Curtiss, L. A. RSC Adv. 2014, 4, 57442-57451.

5. Chiba, S. Synlett 2012, 2012, 21-44.

6. Patil, S.; White, K.; Bugarin, A. Tetrahedron Lett. 2014, 55, 4826-4829.

7. Patil, S.; Bugarin, A. Acta Crystallogr., Sect. E: Struct. Rep. Online 2014, 70, 224-227

8. Patil, S.; Bugarin, A. Eur. J. Org. Chem. 2016, 2016, 860-870.

9. Pogoreltsev, A.; Tulchinsky, Y.; Fridman, N.; Gandelman, M. J. Am. Chem. Soc. 2017, 139, 40624067.

10. Back, J.; Park, J.; Kim, Y.; Kang, H.; Kim, Y.; Park, M. J.; Kim, K.; Lee, E. J. Am. Chem. Soc. 2017, 139, 15300-15303.

11. Barragan, E.; Bugarin, A. J. Org. Chem. 2017, 82, 1499-1506.

12. Barragan, E.; Noonikara-Poyil, A.; Yang, C-H.; Wang, H.; Bugarin, A. Org. Chem. Front. 2019, 6, $152-161$.

13. Zincsuk, J.; Carnavale, G. A. Arkivoc 2016, 4, 352-362. 
14. Pattacini, R.; Jie, S.; Braunstein, P. Chem. Commun. 2009, 890-892.

15. Simmons, H. E.; Smith, R. D. J. Am. Chem. Soc. 1958, 80, 5323-5324.

16. Rossberg, M. , Lendle, W. , Pfleiderer, G., Tögel, A., Dreher, E. , Langer, E. , Rassaerts, H. , Kleinschmidt, P., Strack, H. , Cook, R., Beck, U., Lipper, K. , Torkelson, T. R., Löser, E. , Beutel, K. K. and Mann, T. (2006). Chlorinated Hydrocarbons. In Ullmann's Encyclopedia of Industrial Chemistry, (Ed.).

17. Archer, R. H.; Zones, S. I.; Davis, M. E. Microporous Mesoporous Mater. 2010, 130, 255-265.

18. Lu, Y.; Wang, L.; Wang, X.; Xi, T.; Liao, J.; Wang, Z.; Jiang, F. Eur. J. Med. Chem., 2017, 135, $125-141$.

19. For additional crystallography data of compound 5 in CIF and other formats, see the CCDC 1832942. 